\title{
Trace Element Concentrations Present in Five Species of Freshwater Fish of Bangladesh
}

\author{
M. Nurul Amin*a A. Begum ${ }^{\mathrm{b}}$ and M. G. Kibria Mondal ${ }^{\mathrm{c}}$ \\ ${ }^{a}$ Department of Applied Chemistry and Chemical Engineering, University of Dhaka, Dhaka 1000, Dhaka \\ ${ }^{b}$ Department of Zoology, University of Dhaka, Dhaka 1000, Dhaka and ${ }^{c}$ Department of \\ Chemistry, Jagannath University, Dhaka, Bangladesh.
}

\begin{abstract}
In the present study, the edible portions of whole fish excluding viscera and bone of five different freshwater fish species samples are analysed for lead, manganese, nickel, zinc, copper and iron by atomic absorption spectrophotometry (AAS). The relative standard deviations (RSD) were found below 5\%. The accuracy of the methods was confirmed by certified reference materials. The concentrations of trace elements in the edible portions of other fish comply with the international standards for human consumption.
\end{abstract}

Key words: Trace element; Gumti river; Freshwater fish; Atomic absorption spectrophotometry (AAS); Metal contamination

\section{Introduction}

Concern about the effects of anthropogenic pollution on the freshwater ecosystems is growing. Heavy metals from manmade pollution sources are continuously released into aquatic ecosystems. The contamination of heavy metals is a serious threat because of their toxicity, long persistence, bioaccumulation and biomagnification in the food chain (Eisler, 1988). Fish samples can be considered as one of the most significant indicators in freshwater systems for the estimation of metal pollution level (Barak et al. 1990; Evans et al. 1993; Rashed 2001). In recent years, much attention has been directed to the concentrations of some inorganic elements in freshwater fish and other aquatic organisms (Farkas et al. 2003; Mansour et al. 2002; Moiseenko et al. 2001). The commercial and edible species have been widely investigated in order to check for those hazardous to human health.

Under certain environmental conditions, heavy metals may accumulate to toxic concentrations and cause ecological damage (Jefferies et al. 1984). Fishes are often at the top of the aquatic food chain and may concentrate large amounts of some metals from the water (Mansour et al. 2002). Furthermore, fish is one of the most indicative factors in freshwater systems, for the estimation of trace metals poll

\footnotetext{
* Corresponding author: E-mail: nurul34@hotmail.com
}

tion and risk potential of human consumption (Barak et al. 1990; Papagiannis et al. 2004). The contaminated fish from freshwater environment may become a public health concern. Hence, it is important to determine the concentrations of heavy metals in commercial fishes in order to evaluate the possible risk of fish consumption (Cid et al. 2001).

In the present work, the concentrations of trace elements (lead, manganese, nickel, zinc, copper and iron) in edible portions of five different freshwater fish species are reported.

\section{Materials and Methods}

\section{Sample collection}

The freshwater fish species were sampled in May 1, 2005 and May 3, 2006 by a professional fisherman at two stations (Gumti river), located in Daud Kandi, Comilla. Although a variety of freshwater fish species inhabits this river, the generally edible ones, Corica soborna (Kachki), Clupisoma pseudeutropius atherinoides (Batashi), Gudusia chapra (Chapila), Trypauchen vagina (Lal-Cheu) and Mystus vittatus (Tengra), were chosen for the present work. The fish samples were put in plastic bag/containers and transported to the laboratory on the same day. The internal organs, heads 
and tails of fish, which people do not consume, were removed and the edible portions (muscle) were washed with distilled water. After cutting into small pieces with a cleaned stainless steel knife, the small pieces were cleaned several times with demineralized pure water. The samples were dried in an oven at $65^{\circ} \mathrm{C}$ for $48 \mathrm{~h}$ and were homogenized with a mortar. The powdered samples were dried again at $105{ }^{\circ} \mathrm{C}$ in the oven to a constant weight. Finally, the fine samples were preserved in clean and dry polyethylene bottles.

\section{Chemical analysis}

Accurately weighted fish samples (about $2 \mathrm{~g}$ ) were treated with $10 \mathrm{ml}$ of $14 \mathrm{M}$ nitric acid, $5 \mathrm{ml}$ of $13 \mathrm{M}$ perchloric acid and $5 \mathrm{ml}$ of demineralized pure water in a Teflon decomposition vessel. The vessel was put in a stainless steel container and heated for $2 \mathrm{~h}$ at $150{ }^{\circ} \mathrm{C}$ in an electric oven. After decomposition, the solution was evaporated down to about 5 $\mathrm{ml}$ in a Teflon beaker by heating with a hot plate. Finally, the solution was transferred to a $100 \mathrm{ml}$ volumetric flask and diluted to volume with demineralized pure water. The elemental concentrations in the solution were measured with a Pye Unicam SP-2900 flame atomic absorption spectrophotometer. The standard solutions were prepared in $0.1 \mathrm{~N}$ perchloric acid.

The analytical performance was evaluated using standard reference materials, fish flesh homogenate MA-A-2 (TM), from the international laboratory of marine radioactivity of IAEA, Monaco. The elemental concentrations determined in standard reference materials were in good agreement with the certified values, as shown in Table I. gonads and muscles, of fish (Moiseenko \& Kudryavtseva, 2001; Mzimela, Wepener, \& Cyrus, 2003), but in the present work only fish muscles were evaluated for the elemental concentration since local people do not habitually consume other parts. Table II presents the elemental concentrations in muscle tissues of freshwater fish in Gumti river (Daud Kandi, Comilla). Lead levels in all fishes examined are in the range $0.1 \mathrm{mg} / \mathrm{kg}$ to $0.84 \mathrm{mg} / \mathrm{kg}$ (average $0.31 \mathrm{mg} / \mathrm{kg}$ ) on the wet weight basis, considering the conversion factor of 4.8 for fresh weight. This value is below the provisional tolerable intake of total lead $(7.1 \mu \mathrm{g} / \mathrm{kg}$ body wt/day) by human being (National Research Council, 1989; WHO, 1973; FAO/WHO, 1972-1987; FAO/WHO, 1984). The rough content orders were: iron $>$ zinc $>$ manganese $>$ copper $>$ nickel $>$ lead. These sequences were the same as those obtained in similar freshwater fishes, Bangladesh (Sharif et al. 1993).

In order to evaluate the elemental concentrations in the freshwater fish muscle tissues in Gumti river, we tried to compare the measured values with those in muscle tissues obtained at other places, as shown in Table III. The elemental concentrations in the freshwater fish of different rivers in Bangladesh were investigated in 1993 (Sharif et al. 1993). The results were similar to our values. However, the concentrations of iron, zinc, manganese, copper, lead and nickel in the freshwater fish in Gumti river was much higher than those in Lake Kasumigaura, Japan (Alam et al. 2002).

However, the European Communities (EC, 2001), followed by the European Union (EU), released a commission regulation, setting maximum levels for certain contaminants in

Table I: Analytical results of standard reference materials MA-A-2 (TM) from IAEA

\begin{tabular}{l|c|c|c}
\hline \multirow{2}{*}{ Metal } & \multicolumn{2}{|c|}{ Concentration $(\mu \mathrm{g} / \mathrm{g}$-dry wt) } & \multirow{2}{*}{ Relative variance $(\%)$} \\
\cline { 2 - 4 } & Observed & Certified value & +3.5 \\
\hline $\mathrm{Pb}$ & $0.60 \pm 0.03$ & $0.58 \pm 0.07$ & -1.2 \\
$\mathrm{Mn}$ & $0.80 \pm 0.01$ & $0.81 \pm 0.04$ & -1.8 \\
$\mathrm{Ni}$ & $1.08 \pm 0.03$ & $1.10 \pm 0.20$ & +1.5 \\
$\mathrm{Zn}$ & $33.5 \pm 0.5$ & $33.0 \pm 1.0$ & +3.3 \\
$\mathrm{Cu}$ & $4.13 \pm 0.03$ & $4.0 \pm 0.1$ & -3.2 \\
$\mathrm{Fe}$ & $52.3 \pm 0.8$ & $54.0 \pm 1.0$ & \\
\hline
\end{tabular}

$\mathrm{n}=3$.

\section{Results and Discussion}

Although many researchers have presented the elemental contents in various tissues, such as liver, kidneys, gills, foodstuffs, which included $0.2 \mathrm{mg} / \mathrm{kg}$ wet weight lead level for the muscle meat of fish. Since, the lead content in the muscle of freshwater fish corresponded to $0.31 \mu \mathrm{g} / \mathrm{g}$-wet 


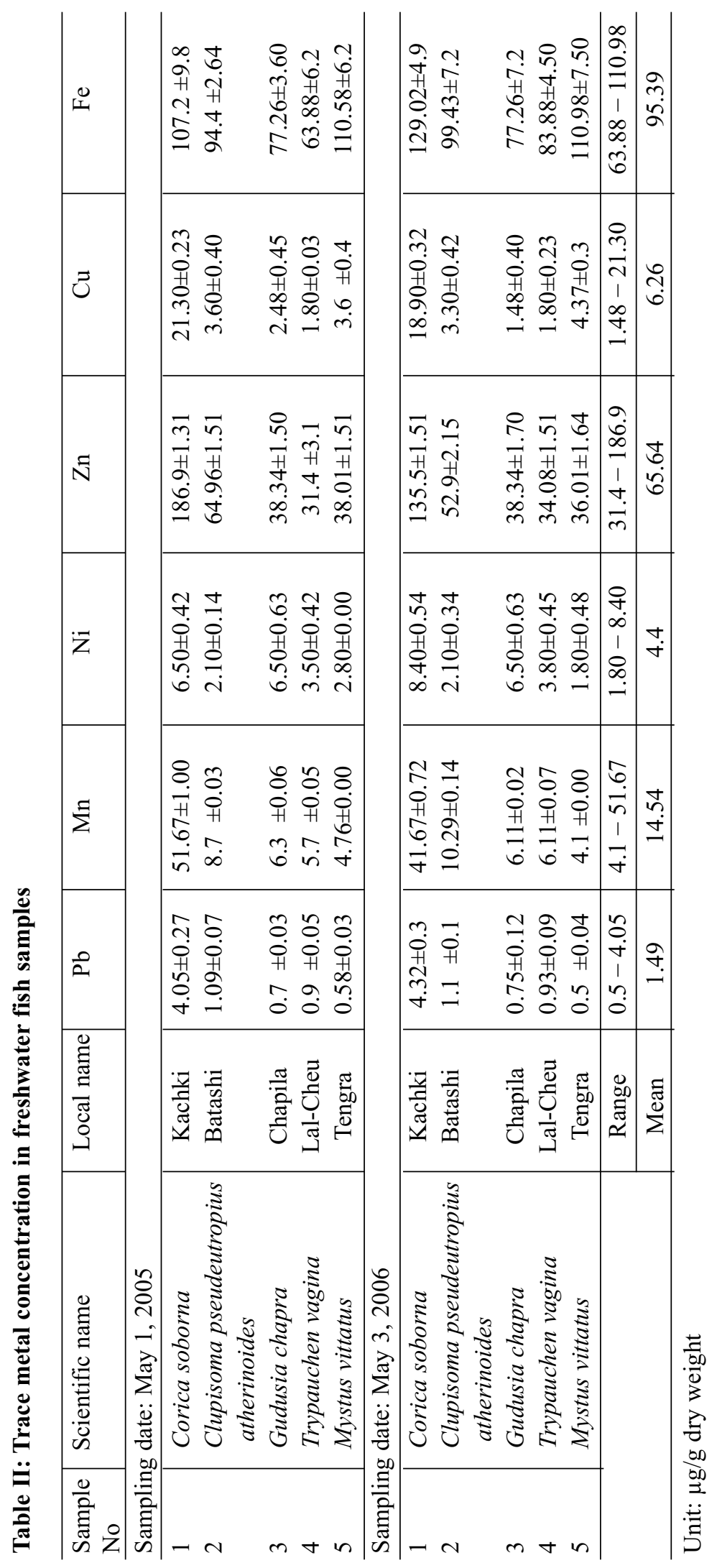




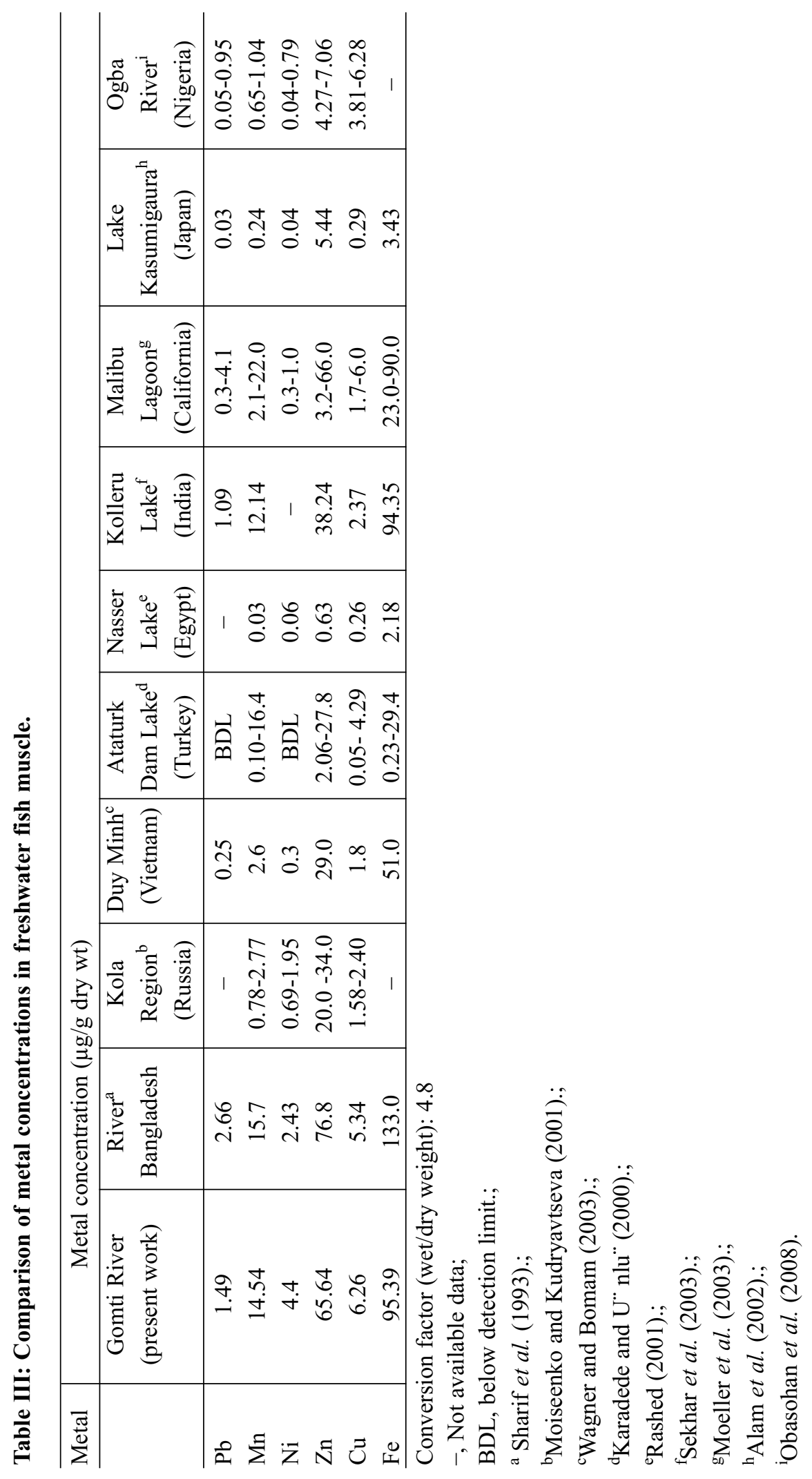


weight, careful attention should be paid to edible freshwater fish species in Bangladesh.

The concentrations of trace elements in edible freshwater fish species in Gumti river, Bangladesh were investigated. The elemental lead contents (Table II) in the freshwater fish muscle tissues were close to the range of international standards of fish (Sharif et al. 1993; Moiseenko and Kudryavtseva 2001; Wagner and Bomam 2003; Karadede and Ünlü 2000; Rashed 2001; Sekhar et al. 2003; Moeller et al. 2003; Alam et al. 2002 and Obasohan et al. 2008). The pollution level of Gumti river seems to become worse as Bangladesh becomes more industrially developed. Information on the levels of metals in the common fish species will be needed to the effective monitoring of both environmental quality and the health of organisms inhabiting the river ecosystem.

\section{Acknowledgements}

The authors are grateful to the Chairman, Department of Zoology, University of Dhaka, Bangladesh for providing the laboratory facilities during the progress of this work. A part of the present work was performed at Mie University, Satellite Venture Business laboratory (SVBL), Japan.

\section{References}

Alam M. G. M., Tanaka A., Allinson G., Laurenson L. J. B., Stagnitti F. and Snow, E. T. (2002). A comparison of trace element concentrations in cultured and wild carp (Cyprinus carpio) of lake Kasumigaura, Japan. Ecotoxicology and Environmental Safety, 53: 348-354.

Barak N. A. E., and Mason C. F. (1990). Mercury, cadmium and lead concentrations in five species of freshwater fish from Eastern England. Science of the Total Environment, 92: 257-263.

Cid B. P., Boia C., Pombo L., and Rebelo E. (2001). Determination of trace metals in fish species of the Ria de Aveiro (Portugal) by electrothermal atomic absorption spectrometry. Food Chemistry, 75: 93-100.

Eisler R. (1988). Zink Hazards to fish, Wildlife and Invertebrates: a synoptic review. US Fish Wildlife Serv. Biology of Reproduction, 85.
European Communities (EC) Commission Regulation. (2001). No. 466/2001 of 8 March 2001 setting maximum levels for certain contaminants in foodstuffs [Official Journal L 77 of 16.03.2001].

Evans D. W., Dodoo D. K. and Hanson D. J. (1993). Trace elements concentrations in fish livers implications of variations with fish size in pollution monitoring. Marine Pollution Bulletin, 26(6): 329-534.

FAO/WHO Joint FAO/WHO Expert Committee on Food Additives 1972-1987, Reports 505, 631, 683, 696 and 751. World Health Organization, Geneva, 1972-1989.

FAO/WHO, Joint FAO/WHO Food Standards Programme, Codex Alimentarius Commission 1984. CAC/Vol XVII, Contaminants, FAO, Rome and WHO, Geneva.

Farkas A., Salánki J. and Specziár A. (2003). Age and sizespecific patterns of heavy metals in the organs of freshwater fish Abramis brama L. populating a low-contaminated site. Water Research, 37: 959-964.

Jefferies D. J. and Firestone P. (1984). Chemical analysis of some coarse fish from a Suffolk River carried out as part of the preparation for the first release of captivebred otters. Journal of Otter Trust, 1(18): 17-22.

Karadede H. and Ünlü E. (2000). Concentrations of some heavy metals in water, sediment and fish species from the Atatürk Dam Lake (Euphrates), Turkey. Chemosphere 41: 1371-1376.

Mansour S. A. and Sidky M. M. (2002). Ecotoxicological studies: 3. Heavy metals contaminating water and fish from Fayoum Gov. Egypt. Food Chemistry, 78: 15-22.

Moiseenko T. I. and Kudryavtseva L. P. (2001). Trace metal accumulation and fish pathologies in areas affected by mining and metallurgical enterprises in the Kola Region. Russian Environmental Pollution, 114: 285297.

Moeller A., MacNeil S. D., Ambrose R. F. and Hee S. S. Q. (2003). Elements in fish of Malibu Creek and Malibu Lagoon near Los Angeles, California. Marine Pollution Bulletin, 46: 424-429. 
Mzimela H. M., Wepener V. and Cyrus D. P. (2003). Seasonal variation of selected metals in sediments, water and tissues of the groovy mullet, Liza dumerelii (Mugilidae) from the Mhlathuze Estuary, South Africa. Marine Pollution Bulletin, 46: 659-676.

National Research Council, 1989. Recommended Dietary Allowances, 10th edn, National Research Council, Washington D.C., U.S.A.

Obasohan E. E. and Eguavoen O. I. (2008). Seasonal variations of bioaccumulation of heavy metals in a freshwater fish (Erpetoichthys calabaricus) from Ogba River, Benin City, Nigeria.

Papagiannis I., Kagalou I., Leonardos J., Petridis D. and Kalfakaou V. (2004). Copper and zinc in four freshwater fish species from Lake Pamvotis (Greece). Environmental International, 30: 357-362.

Rashed M. N. (2001). Monitoring of environmental heavy metals in fish from Nasser lake. Environment International, 27: 27-33.
Sekhar K. C., Chary N. S., Kamala C. T., Raj D. S. S. and Rao A. S. (2003). Fractionation studies and bioaccumulation of sediment bound heavy metals in Kolleru lake by edible fish. Environment International, 29:1001-1008.

Sharif A. K. M., Alamgir M., Mustafa A. I., Hossain M. A. and Amin M. N. (1993). Trace element concentrations in ten species of freshwater fish of Bangladesh. Science of the Total Environment, 138: 117-126.

Wagner A. and Bomam J. (2003). Biomonitoring of trace elements in muscle and liver tissue of freshwater fish. Spectrochimica Acta Part B-Atomic Spectroscopy, 58: 2215-2226.

WHO, 1973. Trace elements in human nutrition, Tech. Rep. Ser. 230, World Health Organization, Geneva.

Received: March 17, 2010;

Accepted : May 19, 2010 